\title{
Microfilaments and FSH stimulation of rat granulosa cell steroidogenesis in vitro
}

\author{
B. K. Tsang, M. Li* and J. A. Carnegie
}

Reproductive Biology Unit, Department of Obstetrics \& Gynecology and Department of Physiology, University of Ottawa, Ottawa Civic Hospital, and The Loeb Institute of Medical Research, Ottawa Civic Hospital, Ottawa, Ontario, Canada KIY 4 E9

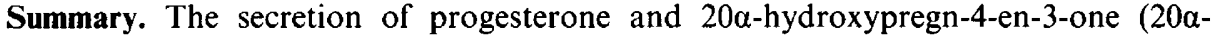
dihydroprogesterone) by granulosa cells from 30 -day-old rats pretreated with PMSG (4 i.u.; i.p.) was significantly increased in a time- and concentration-dependent manner by FSH or cytochalasin B. Whereas FSH markedly stimulated progestagen secretion during $3 \mathrm{~h}$ of incubation, a significant enhancement of the steroidogenic response was not noted until $12 \mathrm{~h}$ of exposure to the inhibitor in vitro. Although cytochalasin $\mathrm{B}$ also enhanced the submaximal stimulation of progestagen production by $\mathrm{FSH}(15 \mathrm{ng} / \mathrm{ml})$, it was ineffective in the presence of maximal stimulatory concentration of the gonadotrophin $(150 \mathrm{ng} / \mathrm{nl})$. With increasing concentrations of cytochalasin $\mathrm{B}$, the ability of FSH to further stimulate progestagen secretion was progressively reduced. Granulosa cells cultured in medium alone contained a prominent cytoplasmic array of microfilaments which was markedly reduced by FSH or cytochalasin B. FSH and, to a greater extent, cytochalasin $\mathrm{B}$ elicited concentration-dependent reductions in the mean area occupied by the cells on the culture surface, the contour index (a size-independent representation of cell profile irregularity) and cell perimeter, indicating that the cells underwent less spreading and were more spherical and regular in outline in the presence of either agent. The FSH-induced reductions in the three shape-related parameters were augmented by cytochalasin B although the influence of the FSH on the mean area and perimeter was progressively reduced in the presence of higher concentrations of cytochalasin $B$. These findings are consistent with the concept that microfilaments influence cell shape and steroidogenesis in granulosa cells in vitro and that FSH alters microfilament distribution and shape of cultured granulosa cells in eliciting its steroidogenic influence.
\end{abstract}

Keywords: microfilaments; steroidogenesis; FSH; granulosa cells

\section{Introduction}

The gonadotrophic control of ovarian steroidogenesis is a complex process involving the regulation of steroidogenic enzyme activities as well as steroid precursor availability (Marsh, 1976). Whereas FSH is known to increase the activities of a number of key steroidogenic enzymes in granulosa cells (Hsueh et al., 1984), how the gonadotrophin influences substrate availability at the enzymic sites is unclear. The production of steroid is believed to involve considerable movement of substrate and intermediates from one intracellular locale to another. While cholesterol, normally stored as esters in lipid droplets, is transported to and taken up by the mitochondria for the synthesis of pregnenolone, further metabolism to progesterone and $20 \alpha$-hydroxy-pregn-4-en-3-one (20a-dihydroprogesterone)

*Present address: Department of Animal Physiology, Fushan Veterinary College, Fushan, Guang Dong, People's Republic of China. 
by $3 \beta$-hydroxysteroid dehydrogenase and $20 \alpha$-hydroxysteroid dehydrogenase, respectively, requires the translocation of the pregnenolone to smooth endoplasmic reticulum where the enzymes are situated (Marsh, 1976; Hsueh et al., 1984). Previous studies from our laboratory have demonstrated that granulosa cells cultured in the presence of FSH, cyclic AMP, a calcium ionophore, cytoskeletonperturbing agents or a supporting collagen matrix retained a primarily spherical configuration with minimal cytoplasmic spreading and secreted significantly more progesterone than did control cells (Carnegie et al., 1987, 1988; Carnegie \& Tsang, 1987, 1988; S. K. Jindal, J. A. Carnegie \& B. K. Tsang, unpublished data). It was also noted that depolymerization of microtubules or microfilaments with colchicine or cytochalasin B, respectively, increased basal progesterone and $20 \alpha-$ dihydroprogesterone production (Carnegie et al., 1987; Carnegie \& Tsang, 1987, 1988). Since the cytoskeleton is believed to be important for the development and maintenance of cell shape as well as the control of the intracellular distribution and/or movement of various organelles, secretory proteins and hormones (Buckley \& Porter, 1967; Olmsted \& Borisy, 1973; Snyder \& McIntosh, 1976), it has been suggested that, in cultured granulosa cells stimulated by FSH, mitochondrial uptake of cholesterol is enhanced due to a closer association between these organelles and lipid droplets, facilitated in part by cytoskeleton-mediated rounding of the cells (Carnegie \& Tsang, 1988).

In the present study we have further examined the relationship between microfilaments and steroidogenesis by investigating the influence of cytochalasin B on basal and FSH-stimulated granulosa cell production of progesterone and $20 \alpha$-dihydroprogesterone in vitro and the effects of these agents on cellular morphology and microfilament distribution.

\section{Materials and Methods}

Ovarian follicular development was initiated in immature Sprague-Dawley rats with an intraperitoneal injection of 4 i.u. PMSG (Equinex: Ayerst Labs, Montreal, Quebec) on the morning of Day $28 \pm 1$. Most follicles had reached the antral stage of development when the ovaries were removed $48 \mathrm{~h}$ later. Granulosa cells, released into Eagle's Minimal Essential Medium (MEM; GIBCO Laboratories, Mississauga, Ontario) by follicle puncture, were collected by centrifugation, as described previously (Tsang \& Carnegie, 1983). Removal of non-viable cells by a sequential trypsin-DNase treatment (Farookhi, 1982) increased the percentage viability of the granulosa cell preparations from an initial value of $20-30 \%$ to a final level of $90-95 \%$. Cells were incubated for $0,3,6,12$ and $24 \mathrm{~h}$ (on coverslips if to be examined subsequently by microscopy) at $36^{\circ} \mathrm{C}$ under an atmosphere of $5 \% \mathrm{CO}_{2}$ and $95 \%$ air in $1 \mathrm{ml} \mathrm{MEM} \mathrm{containing}$ various concentrations of FSH ( $0400 \mathrm{ng}$ NIAMDD-oFSH- $13 / \mathrm{ml})$ and $/$ or cytochalasin B $(0-10 \mu \mathrm{g} / \mathrm{ml})$.

Medium was collected at the end of the incubation period for extraction with ether and determination of progesterone and $20 \alpha$-dihydroprogesterone by specific RIA (Orczyk et al., 1979). The antiserum for the progesterone assay has previously been characterized (Leung \& Armstrong, 1979). With the exception of $8.7 \%$ cross-reactivity with $20 \beta$ hydroxy-pregn-4-en-3-one, the antiserum to $20 a$-dihydroprogesterone cross-reacts minimally $(<0 \cdot 1 \%)$ with other progestagens, oestrogens and androgens (Morley et al., 1987). For both assays, the intra- and interassay coefficients of variation were $<10 \%$ and $<20 \%$, respectively.

Cells grown on coverslips for subsequent investigations of microfilament organization/distribution and cell shape were prepared according to the following protocols.

Morphometric analysis of cell shape changes. Granulosa cells were fixed overnight at $4^{\circ} \mathrm{C}$ in $2 \%$ glutaraldehyde, washed and stained with haematoxylin and eosin. Changes in various cell shape-related characteristics were quantitated using a previously documented procedure (Carnegie et al., 1987). Briefly, random areas of isolated cells were photographed and the film was projected onto a digitizer pad (Summagraphics Corporation, Fairfield, CT, U.S.A.) to enable individual cell outlines to be traced with a cursor. The measures for which data were collected with the use of an MSA II computer program (Atlantic Scientific Systems Group, Ottawa, Canada) and an Apple II Plus microcomputer were: cell perimeter, the surface area occupied by each cell on the coverslip, and the contour index. Contour index is a sizeindependent measurement of the shape of a profile whereby increases in profile irregularity are represented by higher numerical values (Schrek, 1972). A cell taking the shape of a perfect circle is associated with a contour index of 3.54.

Microfilament organization/distribution. Microfilament organization/distribution in granulosa cells was examined using 7-nitrobenz-2-oxa-1,3-diazole-phallacidin (NBD-phallacidin) and a modification of the protocol of Barak et al. (1980), as provided by Molecular Probes Inc. (Eugene, OR, U.S.A.). Cells were washed twice with phosphate-buffered

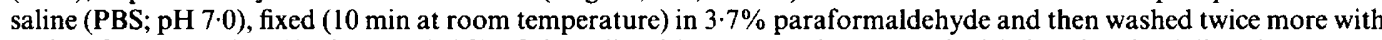
PBS. After extraction $\left(4 \mathrm{~min}\right.$ at $\left.-20^{\circ} \mathrm{C}\right)$ of the cells with acetone, they were air dried and stained $(20 \mathrm{~min}$ at room temperature) with $220 \mathrm{nM}-\mathrm{NBD}$-phallacidin in PBS. The coverslips were then rapidly washed twice with PBS and 
mounted on slides in a 1:1 (v/v) solution of PBS and glycerol before observation with a Carl Zeiss microscope equipped with epifluorescence optics.

Statistical analysis. Results were treated by analysis of variance and the significance of differences between treatment groups was determined by Duncan's new multiple range test or Scheffe's post-hoc comparison test. When there was evidence of heterogeneity of variance, statistical analysis was performed on logarithmically transformed data.

\section{Results}

FSH and cytochalasin B significantly $(P<0.01)$ increased progesterone and 20a-dihydroprogesterone secretion by granulosa cells in vitro (Fig. 1). The concentrations of FSH and cytochalasin $B$ which elicited half-maximal stimulation of total progestagen secretion were approximately $45 \mathrm{ng} / \mathrm{ml}$ and $0.4 \mu \mathrm{g} / \mathrm{ml}$, respectively (Fig. 1). By $3 \mathrm{~h}$ of incubation (earliest time examined), FSH $(15 \mathrm{ng} / \mathrm{ml}$ ) had markedly stimulated progesterone and $20 \alpha$-dihydroprogesterone secretion by 10 - and 6 -fold, respectively. However, a significant increase in progestagen secretion by cytochalasin B was not noted until 6-12 h of culture (Fig. 2).
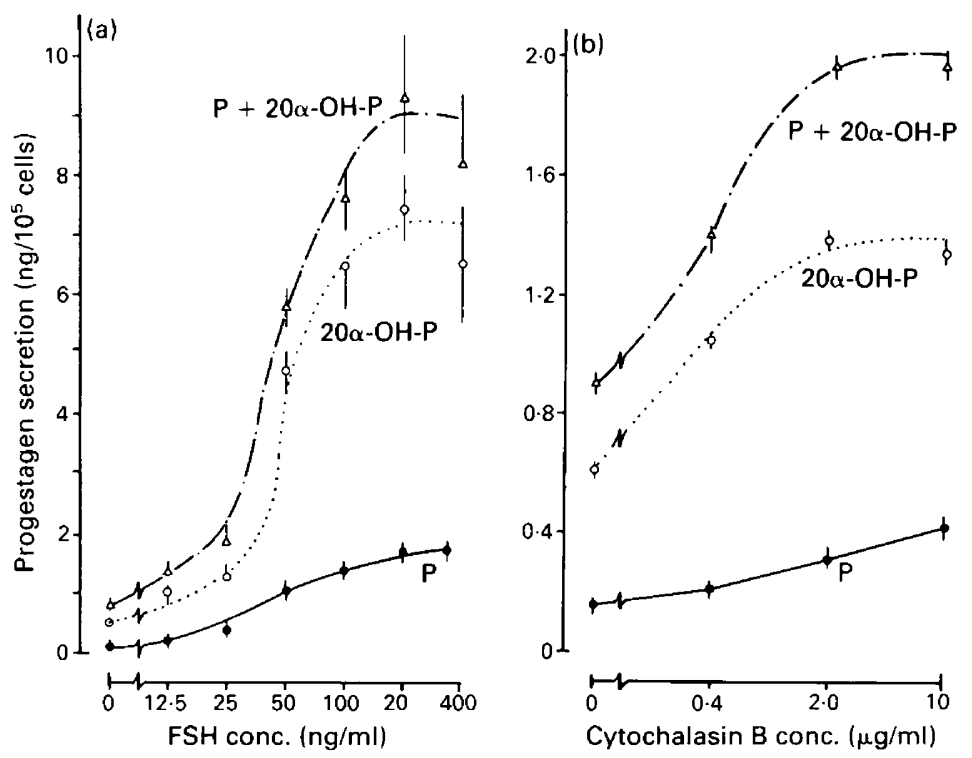

Fig. 1. Concentration-dependent stimulation of basal granulosa cell secretion of progesterone

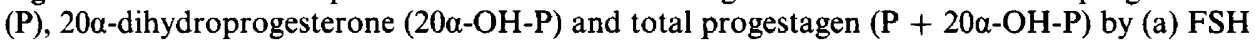
and (b) cytochalasin B during $24 \mathrm{~h}$ of culture. Each point represents the mean \pm s.e.m. of 8 (a, 2 experiments) or 21 (b, 6 experiments) cultures.

Cytochalasin B significantly enhanced the submaximal stimulation of both progestagens by FSH $(15 \mathrm{ng} / \mathrm{ml})$ in a concentration-dependent manner but was ineffective in the presence of a maximally stimulatory concentration of the gonadotrophin $(150 \mathrm{ng} / \mathrm{ml})$. However, with increasing concentrations of cytochalasin B the ability of FSH to further stimulate progestagen secretion was markedly reduced (Fig. 3).

Control cells underwent considerable spreading during $24 \mathrm{~h}$ of culture, and staining of the cells with NBD-phallacidin indicated the presence of parallel bundles of microfilaments (stress fibres) close to the plasma membrane and in the narrow cytoplasmic extensions (Fig. 4a). On the other hand, cells cultured with $10 \mu \mathrm{g}$ cytochalasin $\mathrm{B} / \mathrm{ml}$ remained rounded in vitro and, while positive staining for filamentous actin was still observed, it was reduced in extent and confined to small, 


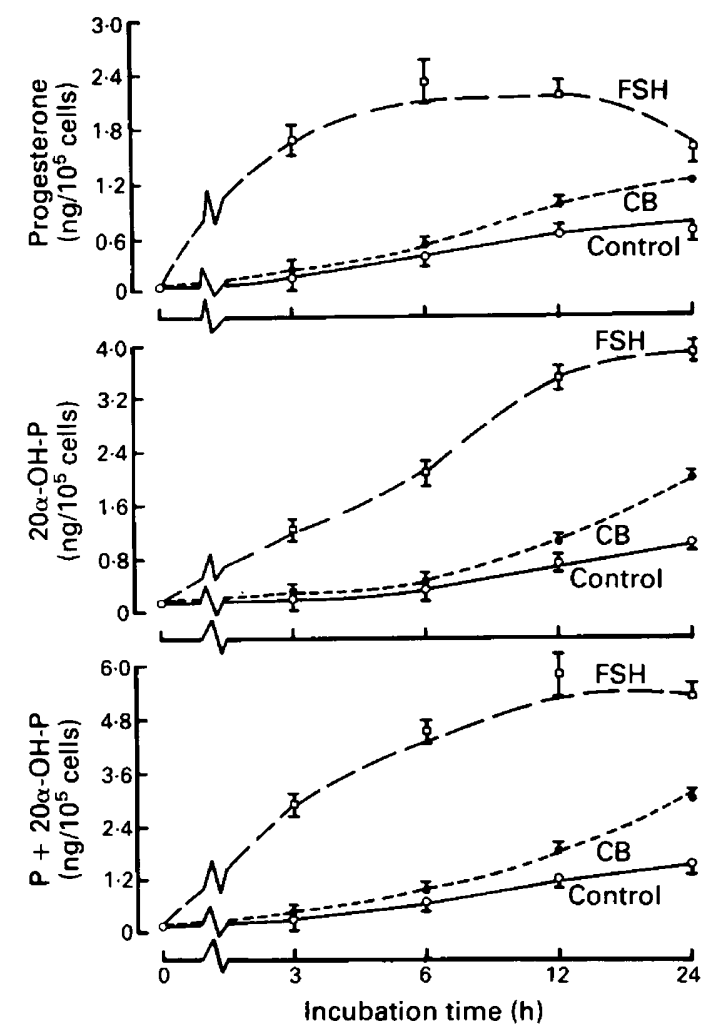

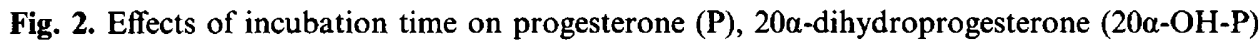
and total progestagen $(\mathrm{P}+20 \alpha-\mathrm{OH}-\mathrm{P}$ ) secretion by granulosa cells in the absence (control) or presence of FSH $(15 \mathrm{ng} / \mathrm{ml})$ or cytochalasin B $(\mathrm{CB} ; 10 \mu \mathrm{g} / \mathrm{ml})$. Each point represents the mean \pm s.e.m. of 12 cultures ( 4 experiments).
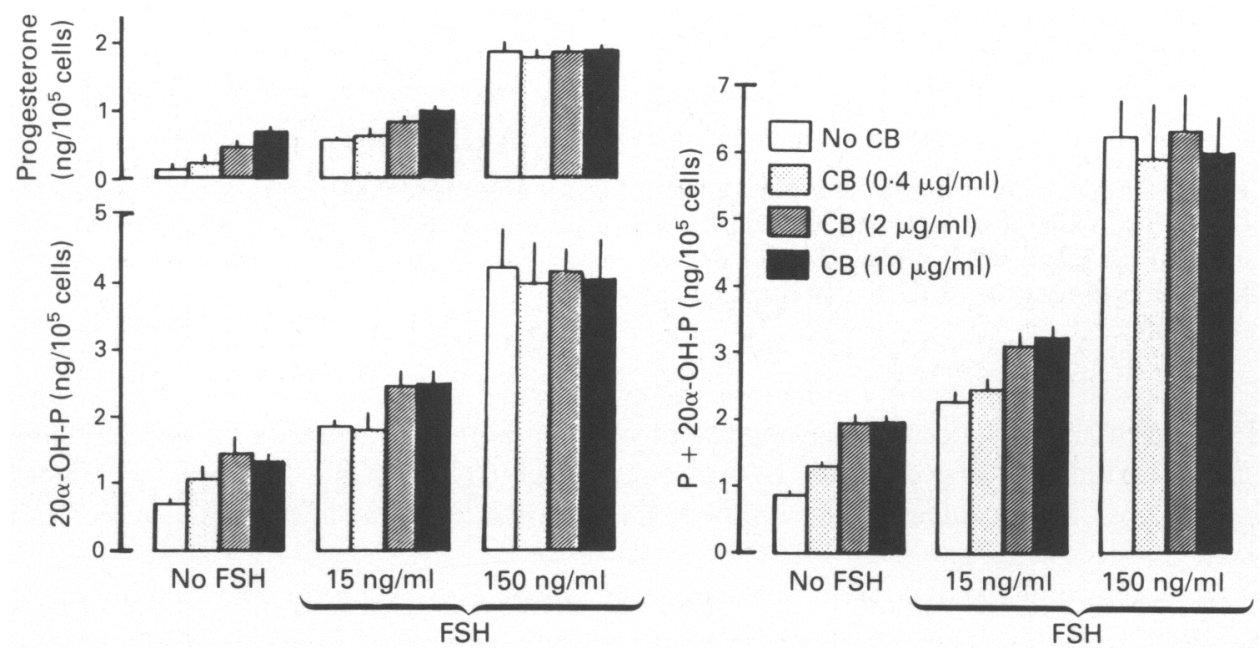

Fig. 3. The influence of various concentrations of cytochalasin B (CB) on basal and FSHstimulated progestagen secretion by granulosa cells during a 24-h culture period. Each histogram represents the mean \pm s.e.m. of 9 cultures ( 3 experiments). 

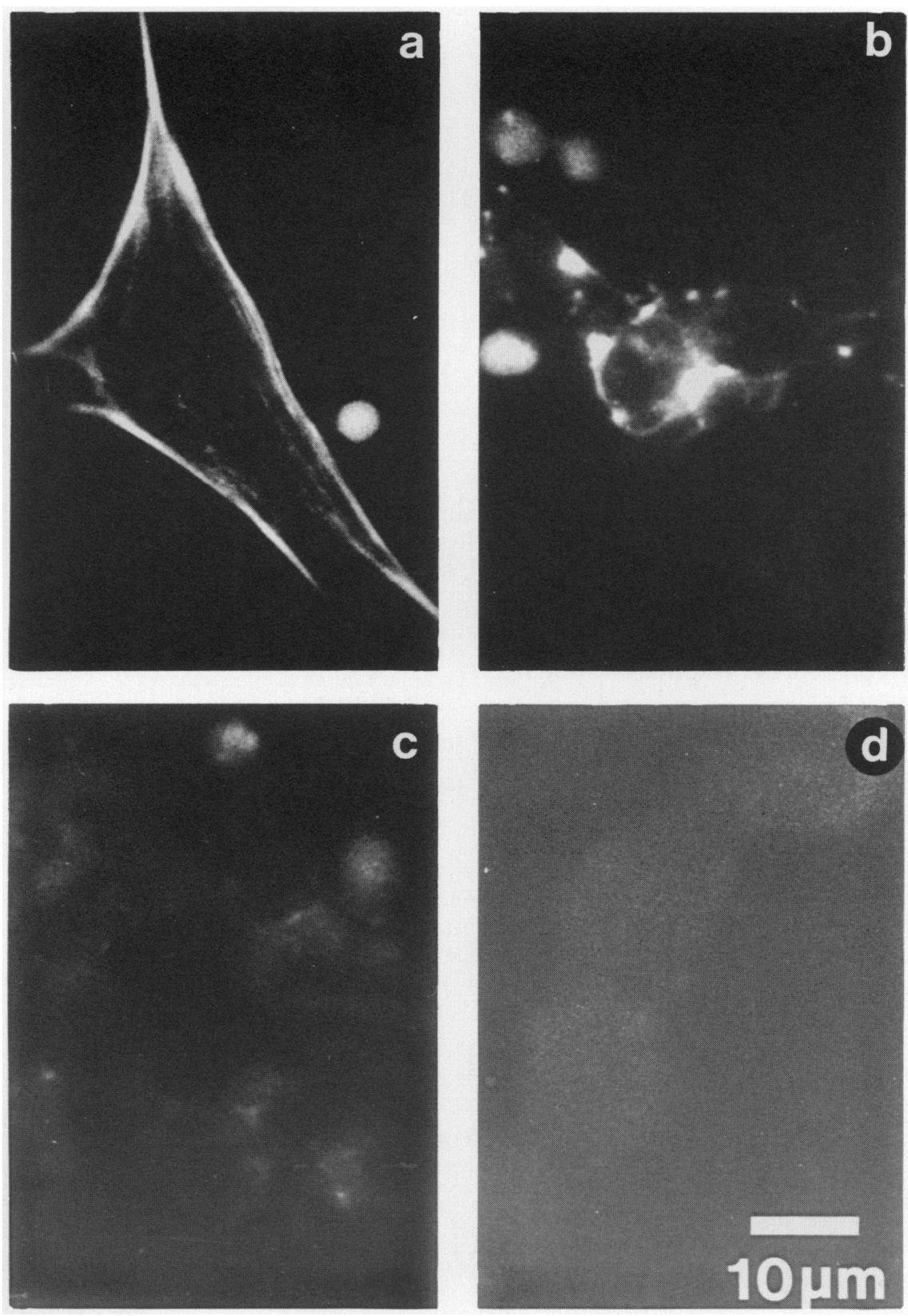

Fig. 4. Granulosa cells stained with NBD-phallicidin to demonstrate the subcellular distribution of actin-containing microfilaments following $24 \mathrm{~h}$ of culture: (a) controls, (b) cytochalasin B $(10 \mu \mathrm{g} \mathrm{ml})$. (c) FSH $(150 \mathrm{ng} \mathrm{ml})$. or (d) FSH + cytochalasin B $(150 \mathrm{ng} \mathrm{ml}$ and $10 \mu \mathrm{g} / \mathrm{ml}$, respectively).

peripheral regions of the granulosa cells (Fig. 4b). Similarly, culture of cells in the presence of $150 \mathrm{ng}$ FSH $\mathrm{ml}$ was associated with a marked decrease in cellular staining with NBD-phallacidin, al hough the cells were not as uniformly rounded as those cultured with cytochalasin B (Fig. $4 \mathrm{c}$ ). In the presence of FSH and cytochalasin B, staining for actin filaments was reduced to such an extent that it was not detectable using this histochemical approach (Fig. 4d). 

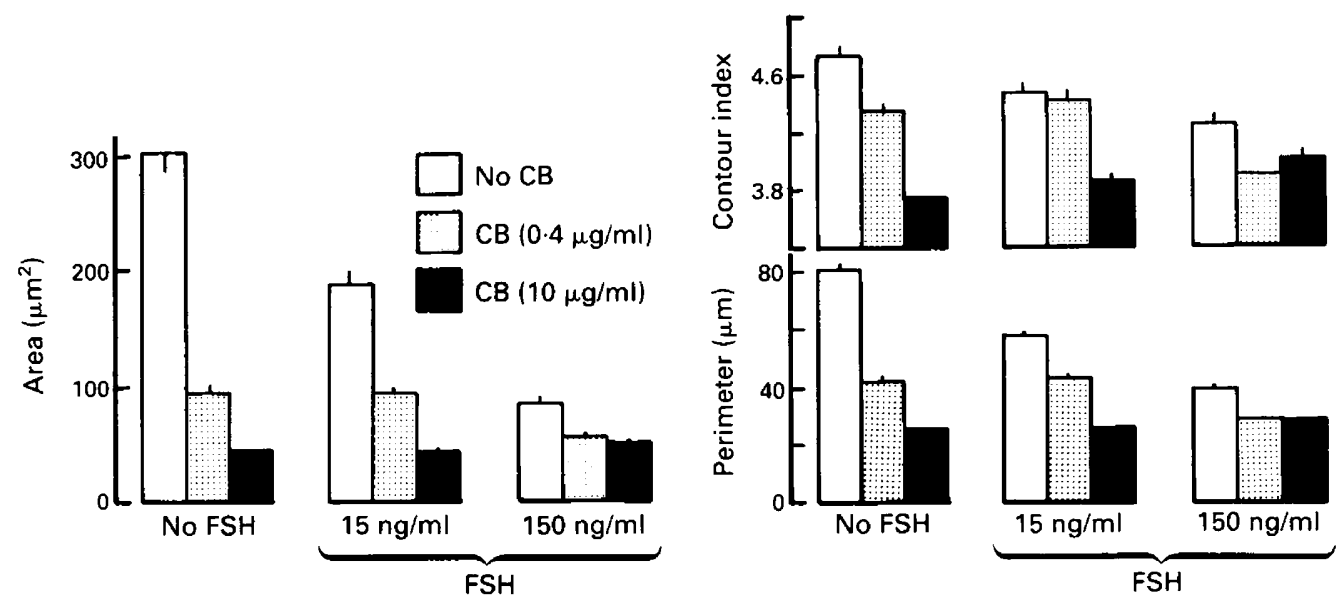

Fig. 5. Changes in the mean area on the coverslips, contour index and perimeter of granulosa cells after $24 \mathrm{~h}$ of culture in the presence of various concentrations of FSH and/or cytochalasin B (CB). Each histogram represents the mean \pm s.e.m. of 99-110 cells.

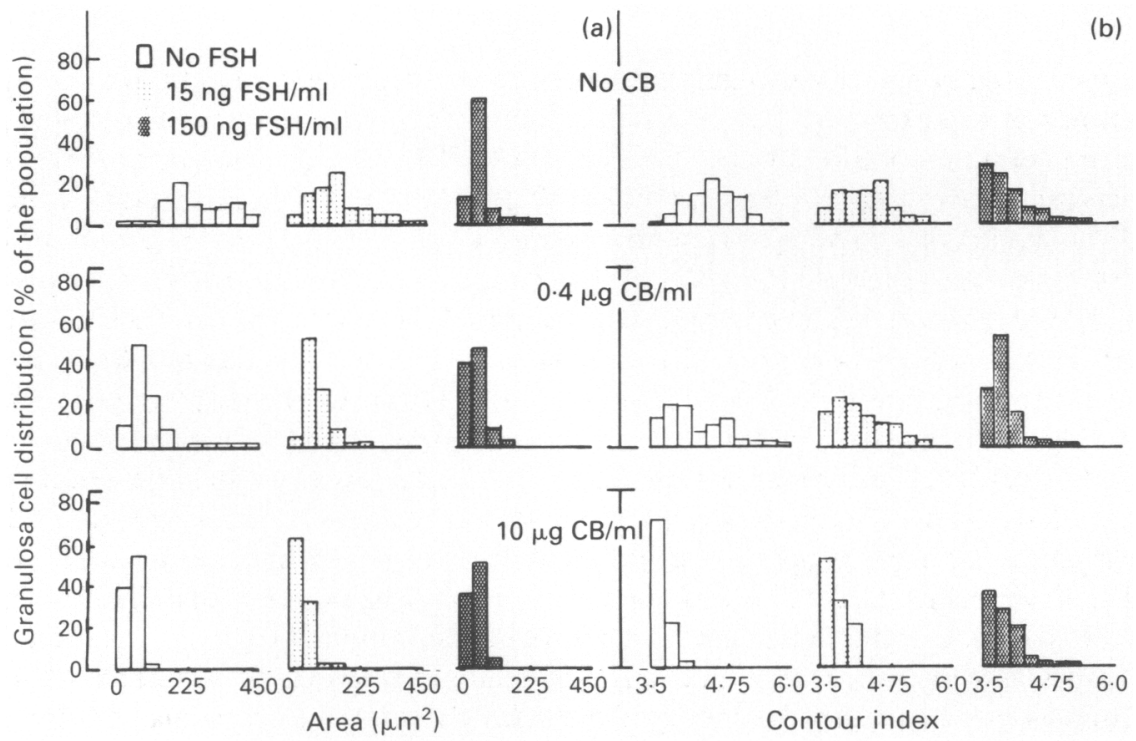

Fig. 6. Concentration-dependent effects of FSH and/or cytochalasin B (CB) on granulosa cell distribution based on area of the culture surface occupied by each cell (a) and on contour index (b) after $24 \mathrm{~h}$ of culture. In (a), each histogram represents $45 \mu \mathrm{m}^{2}$; in (b), each histogram represents a range of 0.3 units. Data were derived from measurements of 94-107 cells per treatment group.

Figure 5 illustrates that the stimulation of progestagen secretion by cytochalasin B or FSH was accompanied by a significant and concentration-dependent decrease $(P<0.001)$ in cell shape measures as outlined below. When cytochalasin B and FSH were both present in the granulosa cell 
cultures, the changes in these shape-related values were greater than those noted in the presence of either agent alone (Fig. 5). However, when granulosa cells were incubated with concentrations of cytochalasin B which maximally stimulated basal progestin secretion $(10 \mu \mathrm{g} / \mathrm{ml}$, Fig. 1b), FSH was no longer effective in eliciting a further decrease in the three shape-related values.

The influence of FSH and cytochalasin B, alone or in combination, on the distribution of the granulosa cell population according to cell areas and contour indices is illustrated in Fig. 6. A mean cell area of $303 \pm 15 \mu^{2}$ for the control group (Fig. 5) represented a broad range of areas with $73 \%$ of the granulosa cell population distributed within the range of 135 to $405 \mu \mathrm{m}^{2}$ (Fig. $6 \mathrm{a}$ ). In the presence of increasing concentrations of FSH or cytochalasin $\mathrm{B}$, the proportion of cells with an area of $<135 \mu \mathrm{m}^{2}$ increased markedly. At $150 \mathrm{ng} \mathrm{FSH} / \mathrm{ml}$ or $10 \mu \mathrm{g}$ cytochalasin $\mathrm{B} / \mathrm{ml}$, over $80 \%$ or $90 \%$ of the cells were $<90 \mu \mathrm{m}^{2}$, respectively. Whereas FSH (150 ng/ml) significantly potentiated the submaximal effect of cytochalasin $B(0.4 \mu \mathrm{g} / \mathrm{ml})$ on cell area it was ineffective in the presence of $10 \mu \mathrm{g}$ cytochalasin $\mathrm{B} / \mathrm{ml}$ (Fig. 6a).

Likewise, contour indices of the control cells were also variable, with the largest division ( $>20 \%$ of the population) observable between 4.7 and 5.0 and with approximately $10 \%$ of the cells associated with other unit intervals between $4 \cdot 1$ and $5 \cdot 1$ (Fig. 6b). FSH or cytochalasin B elicited a concentration-dependent shift in the cell population such that $64 \%$ or $98 \%$ of the cells exhibited contour indices between 3.5 and 4.0 at $150 \mathrm{ng} / \mathrm{ml}$ or $10 \mu \mathrm{g} / \mathrm{ml}$, respectively. Moreover, FSH caused further shifts in contour index distribution of the cell population in the presence of 0.4 but not $10 \mu \mathrm{g}$ cytochalasin B/ml: at $10 \mu \mathrm{g} / \mathrm{ml}$, over $90 \%$ of the cells had contour indices of $<4.0$.

\section{Discussion}

In the current investigation, we have found that concentration-dependent inhibition of microfilament polymerization was associated with a corresponding stimulation of the secretion of both progesterone and $20 \alpha$-dihydroprogesterone in cultured granulosa cells. While such a stimulatory effect of cytochalasin B has been previously reported (Carnegie \& Tsang, 1988), this is the first study in which a time course of the induction of progestagen secretion by this agent and its interaction(s) with FSH in the regulation of granulosa cell steroidogenesis have been examined in vitro. In contrast to the rapid stimulation by FSH, a steroidogenic response of the granulosa cells to the cytoskeletal-perturbing agent was associated with a time lag of $6-12 \mathrm{~h}$. Similarly, a response of ovarian or adrenal cells to the stimulation of steroidogenesis by colchicine, an inhibitor of microtubule polymerization, has been observed during cultures of 6-24h but not in short-term incubations of less than $4 \mathrm{~h}$ (Temple \& Wolff, 1973; Ray \& Strott, 1978; Carnegie et al., 1987). Furthermore, the time-dependency of this effect may, at least in part, explain why previous studies using incubations of up to $3 \mathrm{~h}$ have reported variable effects of cytochalasins on basal steroidogenesis in ovarian cells (Azhar \& Menon, 1981; Gwynne \& Condon, 1982; Silavin et al., 1984). The existence of a time lag also lends support to the concept that microfilament- and microtubule-dependent regulation of granulosa cell steroidogenesis is closely associated with changes in cellular morphology. Although all granulosa cells were rounded in shape at the beginning of the culture period, the cytochalasin B-treated cells remained rounded while the control cells underwent considerable spreading with increasing time in culture. Hence the two treatment groups became increasingly different in terms of both cell shape and the levels of steroid hormone secreted. We have previously suggested that, in granulosa cells in which a rounded cell shape was maintained by the use of microtubule-depolymerizing agents, the stimulation of progestagen production resulted from increased mitochondrial uptake of cholesterol due to a closer association between these organelles and lipid droplets (Carnegie et al., 1987). Further support for this concept comes from our studies in which granulosa cells suspended in collagen matrices remained more rounded and secreted more progesterone than did cells cultured in medium alone (Carnegie et al., 1988). However, the rounded cells cultured in collagen gels were unresponsive to colchicine in terms of progesterone secretion, implying that perturbation of the 
cytoskeleton increased granulosa cell progestagen production only under those conditions in which the treatment also altered cell shape.

Several lines of evidence suggest that microfilaments are involved in the gonadotrophic regulation of granulosa cell steroidogenesis. In this study we found that those concentrations of FSH that gave dose-dependent stimulation of progestagen production reduced the apparent synthesis and bundling of microfilaments into stress fibres and, correspondingly, decreased cell spreading in vitro. Similarly, it has been reported that granulosa cell monolayers incubated with various gonadotrophins underwent transient rounding which was accompanied by a reduction in cellular microfilament content, primarily within the rounded cell bodies rather than the anchoring cytoplasmic extensions (Lawrence et al., 1979; Soto et al., 1986). Furthermore, we have shown in this investigation that inhibition of microfilament polymerization with cytochalasin $\mathbf{B}$ significantly enhanced the steroidogenic response of the granulosa cells to a submaximally-but not a maximallystimulatory concentration of FSH. Conversely, with progressive inhibition of microfilament elongation and accompanying increases in steroidogenesis by cytochalasin B, the ability of FSH to stimulate further these responses was correspondingly reduced. These findings suggest that the action of FSH on granulosa cell progestagen secretion involves in part the regulation of microfilament organization. It is of interest that the stimulation of adrenal cells by ACTH in vitro is accompanied by a reduction in cytoplasmic actin content over a 12 -h period (Cheitlin \& Ramachandran, 1981).

Inhibitory effects of cytochalasins on LH- or hCG-stimulated progesterone production during short-term (up to $3 \mathrm{~h}$ ) incubation of granulosa cells or luteal slices have been reported (Silavin $e t$ al., 1980, 1984; Azhar \& Menon, 1981; Gwynne \& Condon, 1982). While these results appear to be at variance with those obtained in this study, a comparison of the culture conditions suggests another interpretation. Since cytochalasin did not inhibit gonadotrophin-induced cyclic AMP production (Silavin et al., 1980; Azhar \& Menon, 1981), it did not appear to have influenced hormone-receptor binding or actin-regulated movement of the hormone-receptor complex within the membrane (Geiger, 1985). Cells in suspension or incubated as slices would not undergo the intense spreading and exhibit stress fibre formation, as noted in cells cultured for $24 \mathrm{~h}$. Hence the stimulatory action of cytochalasin on granulosa cell steroidogenesis induced by the lower concentration of FSH during $24 \mathrm{~h}$ may reflect the ability of both agents to reduce stress fibre formation and the generation of an elongated, flattened cell form. It would be of interest to evaluate the influence of cytochalasin on FSH-regulated progestagen production by granulosa cells cultured under conditions which allowed them to remain rounded.

The regulation by FSH of microfilament polymerization and organization could profoundly influence organelle distribution within granulosa cells. Microfilaments have been shown to be linked to mitochondria in granulosa cells (Anderson \& Batten, 1980) and to influence their subcellular organization (Soto et al., 1986). The gonadotrophic stimulation of mitochondrial cholesterol uptake is well-established (Marsh, 1976) and may be accomplished in part by bringing mitochondria into closer association with lipid droplets. The present studies suggest that microfilaments are important in the regulation of granulosa cell steroidogenesis by FSH in vitro. The gonadotrophic stimulation of steroidogenesis is accompanied by a loss of these cytoplasmic polymers which may function to increase mitochondrial uptake of cholesterol by interacting with microtubules to bring these organelles into closer proximity with lipid droplets or simply by providing a more pliant cytoplasmic environment favouring organelle redistribution.

We thank Dr D. T. Armstrong and Dr R. E. Gore-Langton (University of Western Ontario, London, Ontario, Canada) for the generous supply of antisera to progesterone and to $20 \alpha$-dihydroprogesterone, respectively; Mr D. Moher for help with the statistical evaluations; and Mrs E. Chan for assistance in the preparation of the manuscript. The studies were supported by grants from the Medical Research Council of Canada (MT7793), State Education Commission, People's Republic of China and the Kiwanis Club of Ottawa Medical Foundation. 


\section{References}

Anderson, E. \& Batten, B.E. (1980) The cytoskeletal system of the cultured ovarian granulosa cell. In Functional Correlates of Hormone Receptors in Reproduction, pp. 261-273. Eds V. A. Mahesh, T. G. Muldoon, B. B. Saxena \& W. A. Sadler. Elsevier North Holland, Inc., New York.

Azhar, S. \& Menon, K.M.J. (1981) Receptor-mediated gonadotropin action in the ovary. Biochem. J. 194, 19-27.

Barak, L.S., Yocum, R.R., Nothnagel, E.A. \& Webb, W.W. (1980) Fluorescence staining of the actin cytoskeleton in living cells with 7-nitrobenz-2-oxa-1,3diazole-phallacidin. Proc. natn. Acad. Sci., U.S.A.77, 980-984.

Buckley, I.K. \& Porter, K.R. (1967) Cytoplasmic fibrils in living cultured cells. A light and electron microscopic study. Protoplasma 64, 40-380.

Carnegie, J.A. \& Tsang, B.K. (1987) Microtubules and the calcium-dependent regulation of rat granulosa cell steroidogenesis. Biol. Reprod. 36, 1007-1015.

Carnegie, J.A. \& Tsang, B.K. (1988) The cytoskeleton and rat granulosa cell steroidogenesis: possible involvement of microtubules and microfilaments. Biol. Reprod. (in press).

Carnegie, J.A., Dardick, I. \& Tsang, B.K. (1987) Microtubules and the gonadotropic regulation of granulosa cell steroidogenesis. Endocrinology 120, 819-828.

Carnegie, J.A., Byard, R., Dardick, I. \& Tsang, B.K. (1988) Culture of granulosa cells in collagen gels: the influence of cell shape on steroidogenesis. Biol. Reprod. (in press).

Cheitlin, R. \& Ramachandran, J. (1981) Regulation of actin in rat adrenocortical cells by corticotropin. $J$. biol. Chem. 256, 3156-3158.

Farookhi, R. (1982) Granulosa cell fusion allows heterologous receptor stimulation of adenylate cyclase and progesterone accumulation. Endocrinology 110, 1061-1063.

Geiger, B. (1985) Microfilament membrane interaction. Trends in Biol. Sci. 10, 456461.

Gwynne, A. \& Condon, W.A. (1982) Effects of cytochala$\sin$ B, colchicine, and vinblastine on progesterone synthesis and secretion by bovine luteal tissue in vitro. J. Reprod. Fert. 65, 151-156.

Hsueh, A.J.W., Adashi, E.Y., Jones, P.B.C. \& Welsh, T.H., Jr (1984) Hormonal regulation of the differentiation of cultured ovarian granulosa cells. Endocrine Review 5, 76-127.

Lawrence, T.S., Ginzberg, R.D., Gilula, N.B. \& Beers, W.H. (1979) Hormonally induced cell shape changes in cultured rat ovarian granulosa cells. J. Cell Biol. 80, 21-36.

Leung, P.C.K. \& Armstrong, D.T. (1979) Estrogen treatment of immature rats inhibits ovarian androgen production in vitro. Endocrinology 104, 1411-1417.

Marsh, J.M. (1976) The role of cyclic AMP in gonadal steroidogenesis. Biol. Reprod. 14, 30-53.

Morley, P., Armstrong, D.T. \& Gore-Langton, R.E. (1987) Fibronectin stimulates growth but not folliclestimulating hormone dependent differentiation of rat granulosa cell in vitro. J. Cell Physiol. 132, 226-236.

Olmsted, J.A. \& Borisy, G.G. (1973) Microtubules. Ann. Rev. Biochem. 42, 507-540.

Orczyk, G.P., Hichens, M., Arth, G. \& Behrman, H.R. (1979) Progesterone and 20 $\alpha$-dihydroprogesterone. In Methods of Hormone Radioimmunoassays, pp. 701-713. Eds B. M. Jaffe \& H. F. Behrman. Academic Press, New York.

Ray, P. \& Strott, C.A. (1978) Stimulation of steroid synthesis by normal rat adrenocortical cells in response to antimicrotubular agents. Endocrinology 103, 1281-1288.

Schrek, R. (1972) Ultrastructure of blood lymphocytes from chronic lymphocytic and lymphosarcoma cell leukemia. J. Natl. Cancer Inst. 48, 51-64.

Silavin, S.L., Moss, G.E. \& Niswender, G.D. (1980) Regulation of steroidogenesis in the ovine corpus luteum. Steroids 36, 229-241.

Silavin, S.L., Javitt, N. \& Strauss, J.F., III (1984) Reevaluation of the effects of cytochalasins on steroidogenesis: studies on hamster granulosa cells. Endocrinology 115, 1511-1516.

Snyder, J.A. \& McIntosh, J.R. (1976) Biochemistry and physiology of microtubules. Ann. Rev. Biochem. 45, 699-720.

Soto, E.A., Kliman, H.J., Strauss, J.F., III \& Paavola, L.G. (1986) Gonadotropins and cyclic adenosine $3^{\prime}, 5^{\prime}$-monophosphate (cAMP) alter the morphology of cultured human granulosa cells. Biol. Reprod. 34, $559-569$.

Temple, R. \& Wolff, J. (1973) Stimulation of steroid secretion by antimicrotubular agents. J. biol. Chem. 218, 2691-2698.

Tsang, B.K. \& Carnegie, J.A. (1983) Calcium requirement in the gonadotropic regulation of rat granulosa cell progesterone production. Endocrinology 113, 763-769.

Received 21 August 1987 